\title{
Gender Difference in Profit Performance — Evidence from the Owners of Small Public Accounting Practices in Taiwan
}

\author{
Chih-Shun Hsu \\ Department of Accounting, Tamkang University \\ New Taipei City, Taiwan \\ E-mail: cshsu@mail.tku.edu.tw \\ Lopin Kuo \\ Department of Accounting, Tamkang University \\ New Taipei City, Taiwan \\ E-mail: lopinkuo@mail.tku.edu.tw \\ Bao-Guang Chang (Corresponding author) \\ Department of Accounting, Tamkang University \\ New Taipei City, Taiwan \\ E-mail: baog@mail.tku.edu.tw
}

Received: Jan. 30, 2013 Accepted: April 8, $2013 \quad$ Published: June 1, 2013

doi:10.5296/ajfa.v5i1.3174 URL: http://dx.doi.org/10.5296/ajfa.v5i1.3174

\begin{abstract}
This study aims to investigate whether the significant difference of the firm's profit performance exits between the male-owned and female-owned small accounting firms. Using data from 1992-2008 small public accounting practice in Taiwan, this study uses a panel data model to estimate the coefficients and to examine the association between gender variable and the firm's profit performance. The findings reveal that the significant difference in profit performance exists between male-owned and female-owned firms in sample. The study can clarify the effects of owner's gender on financial performance of businesses with the
\end{abstract}


explanations that female owners adopt the different management strategies from the male owners. The study also implies that female-owned small businesses are easier to acquire external funds because of their lower risk preference, since the female owners can ensure stable collection of principal and interest. Our study contributes to our understanding of the differences in the profit performance between male-owned and female-owned CPA firms. Not merely can the results of this empirical study provide valuable research implications for women entrepreneurs in the professional accounting practice, but they also provide supplementary in existing accounting literature.

Keywords: Gender Differences, Profit Performance, Small Accounting Practice, CPA Firms, Taiwan 


\section{Introduction}

Research on women businesses has received wide attention in western developed countries, especially in the U. S. and Europe. However, few studies focus on the women businesses in professional service firms. These firms are knowledge-intensive in that they employ educated and certified professionals to provide clients with competent services. This is especially true in the accounting industry. Certified Public Accountants (CPAs) use their professional knowledge to offer clients such services as financial information auditing and financial statements preparation. The nature of these services contributes significantly to the transparency of financial information and the activation of capital markets.

Whilst a couple of studies that deal with how gender differences impacts the owner's performance in CPA firms focus mainly on North America, e.g. US study by Fasci and Valdex (1998), and Canadian study by Collins-Dodd, Gordon, and Smart (2004), the sample used in both studies were less representative, as they included a lower proportion of female owners, and the studies were limited to cross-sectional survey data. Few studies use longitudinal database to explore the effect of gender difference on profit performance amongst Asian entrepreneurs in the professional service firms.

Over the past two decades, Taiwan has witnessed education popularization, for instance, widespread universities - as of 2011, Taiwan has 163 higher education institutions (Ministry of Education, 2012a). Each year, the number of women graduates who are awarded accounting bachelor degrees and above is twice that of men (Ministry of Education, 2012b). This has resulted in more and more women entering the professional services industry, especially accounting professions. According to the Taiwan Financial Supervisory Commission's “2008 Report of Business of the CPA Firms”, nearly 80\% (77.9\%) of CPA professional assistants were held by women. On the level of practicing CPAs, the proportion of women reached 33.1\%. Thus, women account for a significant portion of the accounting workforce. Previous studies pointed out that women are often stereotypically treated as engaging in such soft industries as the general service sector or small-scale retail (Du Reitz \& Henrekson, 2003), but the studies only explore the performance of women businesses in these industries. Yet, the truth of the matter is, the accounting industry has a high percentage of female accountants and attracts many outstanding women, so opportunities for female entrepreneurial hopefuls are clearly higher than other industries. This notwithstanding, accounting literature studies rarely explore whether significant differences exist between performances of female owners of CPA firms and their male counterparts. Therefore our study attempts to address this issue.

Our study with longitudinal data is unique to many female entrepreneurial studies, and the findings contribute to our understanding of the differences in profit performance between male-owned and female-owned CPA firms. The results suggest that: (1) among relatively larger CPA firms, male-owned firms have higher profit performance than female-owned ones; (2) female-owned firms have lower profit performance probably due to their choice of non-attestation services as their main services; (3) female owners have a tendency to provide low-risk services. These findings can clarify the effects of owner's gender on business 
financial performance with support rendered by theoretical explanations in social feminism that female owners adopt different management strategies from male owners. In addition, our study suggests that it is easier for female-owned small businesses to acquire external funds because of their lower risk preference. Fund providers are more willing to offer loans to less risk-seeking business owners as they can ensure stable collection of principal and interest. Not only can results of this empirical study provide valuable research implications for women entrepreneurs in the professional knowledge-intensive industries, they also supplement existing accounting literature.

The remainder of this study is organized as follows: Section Two provides an overview of theoretical framework of gender, entrepreneurship, and firm performance. Section Three explains the research methodology. Sections Four and Five present respectively the empirical results and their implications. Conclusions and suggestions are proposed in the last section.

\section{Literature Review}

\subsection{Gender Role in Business}

Men and women are different in businesses because of unique learning experiences and ways of thinking and rationalizing. This difference is observed with the evidence suggesting that women are generally more risk averse than men (Sexton \& Bowman-Upton, 1990; Powell \& Ansic, 1997; Kepler \& Shane, 2007; Gold, Hunton, \& Gomaa. 2009), and that women owners are more likely to have business that is slow growing and less profitable (Fasci \& Valdez, 1998; Du Reitz \& Henrekson, 2000).

Marlow and Patton (2005) argued that gendered processes shape individuals' assumptions regarding how men and women should play the entrepreneurial roles because socially constructed and learned ideas about gender and entrepreneurship influence men's and women's attitudes and behaviors by making a decision that matches their expectations and views of themselves. For example, empirical evidence suggests men have stronger entrepreneurial intentions than women due to gender stereotype (Gupta, Turbab, Wasti, \& Sikdar, 2009). In the study of gender role in opportunity identification, DeTienne and Chandler (2007) found that women and men have unique stocks of human capital which they adopt differently to identify entrepreneurial opportunities because they have different experiential backgrounds and different ways of thinking (Carter \& William, 2003, p. 30).

Two major schools of thought, namely: liberal feminist theory and social feminist theory, have been offered in the literature and may be applied to explanation of gender role in business. (Fischer et al., 1993; Carter \& William, 2003; DeTienne \& Chandler, 2007; Robb \& Watson, 2011). Liberal feminist theory holds that men's and women's behaviors are different due to situational factors, while social feminist theory assumes gender differences in behavior are caused by dispositional factors (Fischer et al., 1993).

Studies adopting a liberal feminist theory appear to assume that female-owned firms do not perform as well as male-owned firms and then set out to explain this underperformance on the basis of potential discrimination (Ahl, 2006). Previous empirical studies found women are in a more disadvantaged position relative to men in entrepreneurship, mainly because women 
face more barriers in finance access (Fay \& Williams, 1993; Coleman, 2000; Carter, Shaw, Lam, \& Wilson, 2007), or in education, family, and job market (Rosa et al., 1996; Fasci \& Valdez, 1998; Alowaihan, 2004).

In contrast to liberal feminist theory, social feminist theory suggests that men and women differ in their rationality (Fisher et al., 1993). It posits that men and women exhibit fundamentally different views of the world due to differences in their socialization. Gender socialization results in the appearance of difference mode of sharing and delivering knowledge. Thus, according to this perspective, men and women differ in their traits, behaviors, and experiences. Their differences will certainly be reflected in their motivation for entrepreneurship and business performance (Johnsen \& McMahon, 2005).

According to social feminist theory, gender differences are reflected on various aspects of entrepreneurship and business management, for example, female owners seek to take lower risks (Sexton \& Bowman-Upton, 1990; Powell \& Ansic, 1997; Kepler \& Shane, 2007); grow their business more slowly (Fasci \& Valdez, 1998; Du Reitz \& Henrekson, 2000), or attain a better balance between their work and family life (Watson, 2002; Kepler \& Shane, 2007).

Kepler and Shane (2007) found in their sample of US men's and women's new business ventures that male owners spend more effort searching for business opportunities, while female owners are significantly more likely to prefer businesses with a low risk/return ratio. Fischer et al. (1993), in their study of 508 owners (40 female), indicate that at start-up, men have significantly higher levels of experience in managing employees, prior industry experience, and prior entrepreneurial experience. Kalleberg and Leicht (1991) found that men were more likely to be concurrently involved in more than one business venture.

\subsection{Prior Empirical Evidence on Gender and Firm Performance}

The effect of the owner's demographic differences on firm performance is a complicated issue, particularly since management literature examining gender effect on firm performance yielded results that are far from unequivocal. First of all, entrepreneur's gender significant influences a firm's financial performance. For instance, female owners are usually unfairly treated in the acquisition of entrepreneurship funds. It is known that many banks set a higher requirement of collaterals and interest rate or a lower credit line for female-owned small businesses than for male-owned ones (Ahl, 2006; Coleman, 2000; Riding \& Swift, 1990). Female owners have to bear high capital cost of business expansion, so it is harder for them to boost their firms' financial performance. In addition to gender discrimination, women face numerous barriers in operating a business, barriers stemming from their family roles and a lack of socialization, education opportunities, and social connections (Goffee \& Scase 1983; Fasci \& Valdez, 1998; Fischer et al., 1993). As a result, in terms of financial performance, female-owned businesses usually do not fare as well as male-owned businesses.

Similar findings can also be found among a wide array of studies using SMEs as empirical subjects. These studies include a British study on 600 small sole-proprietor firms across textile and clothing, service, and hospitality industries (Rosa et al., 1996), a survey study of 372 small businesses in northeast US (Chaganti \& Parasuraman, 1996), a study of female 
underperformance in 4,200 small businesses in Sweden (Du Rietz and Henrekson, 2000), a survey study of 840 micro, small, and medium-sized enterprises in Laos (Inmyxai and Takahashi, 2010), a performance contrast of 604 US accounting firms (Fasci \& Valdez, 1998), and a comparative study of 560 small businesses in Kuwait (Alowaihan, 2004). Most of these studies indicate that male-owned businesses generate significantly more sales revenue than female-owned ones, mainly because of their owners' attitude in business operations. They mention that male owners are better at using strategies to expand their business and growth. In contrast, female owners are not good at business expansion and are also less concerned about how to boost their business growth.

Previous studies also found that owner's gender is not a determinant of firm performance. Kalleberg and Leicht (1991), for instance, pointed out that while male owners stress product diversity, female owners are more concerned about product quality. Despite their difference in business concerns and use of strategies, such gender difference does not significantly affect their business performance. However, why male and female owners adopt different strategies was not explained in their study. Loscocco and Leicht (1993) investigated economic success among female- and male-owned small businesses in computer, food, and health industries in Indiana. Their findings echoed the conclusion of Kalleberg and Leicht (1991). The findings in Collins-Dodd et al. (2004) suggested that owner's gender alone does not affect a firm's financial performance; however, owner's gender moderates the relations of firm characteristics (for example, number of full-time employees) and owner's properties (for example, age, year of experience) to firm performance. Both Watson (2002) and Johnsen and McMahon (2005) examined the relationship between owner's gender and firm performance (using ROE and ROA as proxy variables for firm performance) in an Australian sample taken from BLS. Their findings also revealed that gender is not a significant determinant of firm performance and growth.

The aforementioned studies provided empirical evidence of the relationship between owner's gender and firm performance in a wide array of industries. However, most of these industries are small-sized manufacturing or service industries. Among them, only Fasci and Valdez (1994) and Collins-Dodd et al. (2004) examined the relationship in the accounting industry, which is a professional service industry characterized by high knowledge intensity, low requirement of asset investment, and high demand for professional labor force (Nordenflycht, 2010). It differs greatly from general manufacturing, retail or service industries, in which many economic activities are based on a bureaucratic structure. CPA firms have their distinct characteristics such as professional autonomy (for example, self-disciplinary mechanisms) and social status (for example, professional education and certification). They also have developed organizational characteristics (for example, sole-proprietorship, professional partnership, and professional firm) and a unique governance model (Morris \& Empson, 1998; Greenword, Hinings, \& Brown, 1990). In their governance model, the responsibilities of the entrepreneur include not only management and operation of the firm but also strategic management of knowledge, that is, creation, maintenance, and update of professional knowledge. Therefore, factors affecting a CPA firm's performance may not be the same as those affecting performance of firms in other industries, and the entrepreneur's gender, 
particularly, as one of determinants of firm's performance is worth investigating.

A review of previous studies also revealed the following limitations. First, in the application of theories, except for Alowaihan (2004), Johnsen and McMahon (2005), and Watson (2002), most previous studies do not employ a theoretical framework to explain women underperformance in business. Fischer et al. (1993) pointed out that gender difference in education and unequal mechanisms for the two genders in society will not result in women underperformance. Rather, women underperformance probably stems from potential differences related to socialization or social experiences.

Besides, in the choice of research subjects, previous research seldom used a longitudinal archival dataset of a single industry in a single nation to examine the effects of entrepreneur's gender. A few studies obtained samples from a single nation, but across multiple industries. As the competitive environment varies from industry to industry, this heterogeneity of competitive environment may significantly affect the empirical results (Lei \& Slocum, 2005). Hence, it is not easy to verify whether entrepreneur's gender is a determinant of firm performance using a sample drawn from multiple industries.

Finally, in the choice of a variable of financial performance, most previous studies used operating revenue of the year as a measure of firm performance (Rosa et al., 1996; Chaganti \& Parasuraman, 1996; Alowaihan, 2004; Du Rietz \& Henrekson, 2000; Inmyxai \& Takahashi, 2010; Watson, 2002; Kalleberg \& Leicht, 1991; Collins-Dodd et al., 2004). Some studies used other variables, such as ROA and ROE, to measure firm performance (Watson, 2002; Johnsen \& McMahon, 2005). However, with the exception of Fasci and Valdez (1998), research scarcely focused on the relationship between owner's gender and profit performance. Profit performance is vital to a firm's survival. It reflects a firm's market strategies for its products or services and its owner's ability to operate and manage the firm (Palupu, Healy, Bernard, \& Peek, 2009).

After having reviewed the literature and its arguments relating to gender and firm performance, this study is aimed at investigating the role of owner's gender in the firm's performance. We take social feminist view to argue that different socialization experiences shape different approaches to businesses among men and women owners. Women tend to provide less risk business, however, lower risk brings lower profit, and ultimately women-led firms have underperformed. Thus we expect that a profit performance for CPA firms will differ by gender, such that female owners are likely to underperform than males.

\section{Research Methodology}

\subsection{Data Collection and Sample}

Data were extracted from "Survey Reports on the Business of CPA Firms" released by Department of Statistics, Ministry of Finance, or Financial Supervisory Commission, Executive Yuan during 1992 and 2008. The sampling period spanned 17 years, and the subjects were registered CPA firms in Taiwan ${ }^{1}$. Because this study was concerned with the

\footnotetext{
${ }^{1}$ Financial Supervisory Commission, Executive Yuan, was mandated to conduct this survey since 2004.
} 
relationship between entrepreneur's gender and profit performance among CPA firms owned by one person, only sole-proprietor CPA firms were selected.

CPA firms without data spanning at least two consecutive years or with missing values for any column were excluded. Basically, the sample consisted of unbalanced panel data obtained from 7,281 CPA firms-year.

\subsection{Variable Measurement}

Dependent Variable: Based on Fasci and Valdez's (1998) method, we used profit rate (PROFIT) as a dependent variable in this study. Among sole-proprietor CPA firms, not every owner gets paid on a monthly basis. Some get their salary after annual closing of their total service revenue. To ensure congruence of this variable across the sample, we defined PROFIT as the ratio of net income before tax plus owner's salary divided by total service revenue.

Research Variable: Entrepreneur's gender (GENDER) is the research variable in this study. It is a dummy variable coded 1 for male and 0 for female.

Control Variables: (1) Number of employees (EMPO): The total number of employees in the CPA firm (including the owner) (see Greenwood, Prakash and Deephouse 2005; Chen, Chang and Lee 2008); (2) Firm's age ( $A G E$ ) refers to how many years the firm has been in operation. It has been argued that a firm has more cost-down advantage if it can enter the market earlier. Bröcheler, Maijoor, and Witteloostuijn (2004) and Chen et al. (2008) also found that older CPA firms generally have better business performance; (3) Service diversification (DIVERSE): A CPA firm provides a variety of professional services. By providing diverse services, it can reduce risks, increase profits, and further enhance its competitiveness in the market. According to Chen et al. (2008), service diversification is positively related to business performance $(P E R F)$. We measured this variable using a Herfindahl index (Sherer, 1995; Hitt, Bierman, Shimizu \& Kochhar, 2001), and deducted from 1. (4) Human capital $(H C)$ : A CPA firm relies heavily on employees with professional accounting knowledge and experience to provide services to its clients. The human capital of these employees affects the CPA firm's business performance. Bröcheler et al. (2004) found that human capital significantly impacts a firm's performance. This variable was measured by the experience and weight of each type of employees (partner, professionals, and other employees) in a CPA firm. According to the Texas Society of Certified Public Accountants (1997-2000), the weights of experience of partners, professionals, and other employees among US CPA firms are in the proportions 6:2:1. (5) Number of branches $(B R A N C H)$ refers to the number of branches operated by the CPA firm (see Greenwood et al., 2005; Chen et al., 2008).

\subsection{Empirical Model}

CPA firms without data spanning at least two consecutive years were not included in the sample. We attempted to use a panel data model to estimate the coefficients. However, whether a fixed-effect model or a random-effect model would be more suitable was determined by the results of Hausman test (Kennedy, 1992). Our estimation model is as follows: 


$$
\begin{aligned}
\operatorname{PROFIT~}_{i t}= & \beta_{0}+\beta_{1} G E N D E R_{i t}+\beta_{2} E M P O+\beta_{3} A G E_{i t}+\beta_{4} D_{I V E R S E} \\
& +\beta_{5} H C_{i t}+\beta_{6} \text { BRANCH }_{i t}+e_{i t}
\end{aligned}
$$

\section{Empirical Results}

\subsection{Descriptive Statistics}

Table 1 shows each variable's descriptive statistics. The sample had an average profit rate of 18 percent and consisted of 77 percent male-owned firms. In other words, owners of this type of professional service firms were mostly male. The average business scale was NT\$3.81 million.

Table 1. Descriptive Statistics (1992-2008, N=7.281)

\begin{tabular}{lcccccc}
\hline \multirow{2}{*}{ Variable } & \multicolumn{2}{c}{ Entire sample } & \multicolumn{2}{c}{ Large-sized firms } & \multicolumn{2}{c}{ Small-sized firms } \\
\cline { 2 - 6 } Profit Rate & Mean & S.D. & Mean & S.D. & Mean & S.D. \\
Gender & 0.18 & 0.21 & 0.20 & 0.13 & 0.18 & 0.26 \\
Number of Employees & 0.77 & 0.42 & 0.81 & 0.39 & 0.74 & 0.44 \\
Age of the firm & 3.81 & 3.14 & 6.01 & 3.00 & 1.55 & 0.82 \\
Service Diversification & 11.29 & 8.48 & 12.22 & 7.61 & 10.33 & 9.20 \\
Human Capital & 0.43 & 0.18 & 0.47 & 0.14 & 0.39 & 0.20 \\
Number of branches & 8.40 & 4.44 & 6.51 & 2.39 & 10.34 & 5.17 \\
\hline
\end{tabular}

Profit differences between large and small firms became evident after we divided the sample into two groups, large and small, using the median of service revenue. Large CPA firms had an average profit rate of 20 percent with a smaller standard deviation (0.13), and small CPA firms had an average of 18 percent with a higher standard deviation (0.26). In terms of each group's gender composition, 81 percent of large CPA firms were male-owned, and 74 percent of small CPA firms were male-owned. This finding revealed that female owners tended to run smaller firms.

In addition, to better understand differences among the four groups, we divided the sample into large and small CPA firms, first by gender and then by median of service revenue. Unlike Table 1, Table 2 showed that large and male-owned CPA firms had a profit rate of 20 percent, which was higher than that of small and male-owned ones (17 percent). Female-owned firms showed just the opposite. Small and female-owned CPA firms had a higher profit rate (20 percent) than large ones (18 percent). Among all large CPA firms, male-owned ones enjoyed a higher profit rate (20 percent) than female-owned ones (18 percent). 
Table 2. Descriptive Statistics - by Gender

\begin{tabular}{lcccccccc}
\hline & \multicolumn{3}{c}{ Male (5,606 persons) } & \multicolumn{3}{c}{ Female (3,058 persons) } \\
\cline { 2 - 10 } & \multicolumn{3}{c}{ Large-sized firms } & \multicolumn{2}{c}{ Small-sized firms } & \multicolumn{2}{c}{ Large-sized firms } & \multicolumn{2}{c}{ Small-sized firms } \\
(2,992 persons) & $(2,654$ persons) & \multicolumn{2}{c}{$(1,441$ persons) } & \multicolumn{2}{c}{$(1,578$ persons) } \\
Variable & Mean & S.D. & Mean & S.D. & Mean & S.D. & Mean & S.D. \\
\hline Profit Rate & 0.20 & 0.13 & 0.17 & 0.25 & 0.18 & 0.11 & 0.20 & 0.29 \\
Number of Employees & 6.15 & 3.15 & 1.59 & 0.82 & 5.43 & 2.16 & 1.44 & 0.82 \\
Age of the firm & 12.79 & 7.96 & 11.68 & 10.00 & 9.83 & 5.25 & 6.54 & 4.66 \\
Service Diversification & 0.48 & 0.14 & 0.40 & 0.19 & 0.45 & 0.15 & 0.36 & 0.20 \\
Human Capital & 6.67 & 2.53 & 10.74 & 5.30 & 5.84 & 1.49 & 9.23 & 4.59 \\
Number of branches & 0.08 & 0.28 & 0.08 & 0.27 & 0.10 & 0.30 & 0.01 & 0.07 \\
\hline Note: See Table 1 for explanation for each variable. & & & & & & & &
\end{tabular}

Finally, Table 3 presents the Pearson correlation coefficients of the entire sample. The correlation coefficient between profit rate and owner's gender was not significantly different from zero, and all the coefficients were smaller than 0.5 in absolute value, implying the level of autocorrelation was low.

Table 3. Correlation Matrix (entire sample)

\begin{tabular}{|c|c|c|c|c|c|c|c|}
\hline & 1 & 2 & 3 & 4 & 5 & 6 & 7 \\
\hline 1. Profit Rate & 1 & & & & & & \\
\hline 2. Gender & -.002 & 1 & & & & & \\
\hline 3. Number of Employees & $.048^{* *}$ & $.115^{* *}$ & 1 & & & & \\
\hline 4. Age of the firm & $-.071^{* * *}$ & $.213^{* *}$ & $.139^{* * *}$ & 1 & & & \\
\hline 5. Service Diversification & .015 & $.103^{* * *}$ & $.249^{* * *}$ & $.067^{* * *}$ & 1 & & \\
\hline 6. Human Capital & $.202^{* * *}$ & $.075^{* * *}$ & $-.423^{* * *}$ & $.198^{*}$ & $-.211^{* * *}$ & 1 & \\
\hline 7. Number of branches & -.021 & $.053^{* * *}$ & $.085^{* * *}$ & $.093^{* * *}$ & $.045^{* * *}$ & -.014 & 1 \\
\hline
\end{tabular}

\subsection{Regression Analysis}

Our sample consisted of sole-proprietor CPA firms in Taiwan from 1992 to 2008. We divided the sample into two groups, large and small, using scale of service revenues, and adopted a heteroskedastic panel data model. Regression results are shown in Table 4. The Hausman test result did not reject the null hypothesis of using the random-effect model. Hence, all the subsequent analyses were based on estimated coefficients of the random-effect model.

First, we examined the effect of owner's gender on profit performance. Results indicated that 
the effect was not statistically significant. According to Fasci and Valdez (1998), Collins-Dodd et al. (2004), and Johnsen and McMahon (2005), firm size generally has a significant impact on the earning power of SMEs. Thus, using median of service revenues, we divided the sample into large firms and small firms and conducted regression analysis of each group respectively ${ }^{2}$.

As shown in Table 4, entrepreneur's gender was not a significant factor affecting the profit performance of small-sized CPA firms. However, owner's gender was a significant factor of profit performance among large-sized firms. The coefficient was 0.012 and significant at 5 percent $(t=2.0134)$. In terms of standardized coefficients, the coefficient of large-sized CPA firms (0.0380) was about seven times of that of small-sized ones (0.0053), suggesting that owner's gender had a relatively great influence on the profit performance of large-sized firms.

Table 4 . Regression Analysis Results

\begin{tabular}{|c|c|c|c|c|c|c|c|c|c|}
\hline \multirow[b]{2}{*}{ Variable } & \multicolumn{3}{|c|}{ Entire Sample } & \multicolumn{3}{|c|}{ Large firms } & \multicolumn{3}{|c|}{ Small firms } \\
\hline & $B$ & Beta & $t$ & $B$ & Beta & $t$ & $B$ & Beta & $t$ \\
\hline Intercept & $0.2144^{* * *}$ & -0.0234 & 7.5291 & $0.3901^{* * *}$ & -0.0159 & 15.7724 & $0.2359^{* * *}$ & 0.0034 & 4.7692 \\
\hline Gender & -0.0111 & 0.0140 & -0.8129 & $0.0122^{* *}$ & 0.0380 & 2.0134 & 0.0032 & 0.0053 & 0.2774 \\
\hline Number of Employees & $-0.0632^{* * *}$ & -0.2100 & -9.3984 & $-0.0787^{* * *}$ & -0.2971 & -13.1544 & $-0.1127^{* * *}$ & -0.2568 & -9.0858 \\
\hline Age of the firm & $-0.0057^{*}$ & -0.0238 & -1.6435 & $-0.0339^{* * *}$ & -0.1815 & -10.2907 & -0.0031 & -0.0109 & -0.5276 \\
\hline $\begin{array}{l}\text { Service } \\
\text { Diversification }\end{array}$ & $0.1003^{* * *}$ & 0.0743 & 6.1698 & $0.0554^{* * *}$ & 0.0625 & 4.1407 & $0.0748^{* * *}$ & 0.0554 & 3.3410 \\
\hline Human Capital & $0.0246^{* * *}$ & 0.0509 & 2.5799 & $0.0175^{* *}$ & 0.0427 & 2.1738 & $0.0295^{*}$ & 0.0485 & 1.7567 \\
\hline Number of branches & 0.0056 & 0.0071 & 0.5533 & $-0.0165^{* *}$ & -0.0367 & -2.1878 & $0.0408^{* *}$ & 0.0368 & 2.0419 \\
\hline Hausman test: & \multicolumn{3}{|c|}{2.7752} & \multicolumn{2}{|c|}{9.6391} & \multicolumn{4}{|c|}{2.2923} \\
\hline$\chi^{2}$ ( $p$ value) & \multicolumn{3}{|c|}{$(0.9050)$} & \multicolumn{3}{|c|}{$(0.1407)$} & \multicolumn{2}{|c|}{$(0.8909)$} & \\
\hline $\bar{R}^{2}$ & \multicolumn{3}{|c|}{0.0536} & \multicolumn{2}{|c|}{0.1583} & \multicolumn{4}{|c|}{0.0893} \\
\hline Sample size & \multicolumn{2}{|c|}{7,281} & & \multicolumn{2}{|c|}{3,694} & \multicolumn{4}{|c|}{3,587} \\
\hline
\end{tabular}

To understand the effect of owner's gender on profit performance among large-sized firms, we divided the sample of large-sized firms into two groups by owner's gender, male-owned and female-owned. The results shown in Table 5 suggested that for both male-owned and female-owned CPA firms, both number of employees (EMPO) and firm age (AGE) were

\footnotetext{
${ }^{2}$ The total asset of each sample firm was absent in the chosen dataset. Although we could obtain data about the number of employees of each firm, most CPA firms had a small and same number of employees. If we divided the sample by median of the number of employees, a large number of firms could not be properly classified. Thus, we used service revenue as a proxy variable for firm size.
} 
negatively related to profit performance. However, service diversification (DIVERSE) was positively related to profit performance. In other words, higher service diversification led to higher profit performance. The effect of human capital (HC) was positive for male-owned CPA firms but negative for female-owned ones. The effect of number of branches (BRANCH) was not significant for both groups of firms.

Table 5. Estimation Result for Large Firms Classified by Gender

\begin{tabular}{|c|c|c|c|c|c|c|}
\hline \multirow[b]{2}{*}{ Variable } & \multicolumn{3}{|c|}{ Male owners } & \multicolumn{3}{|c|}{ Female owners } \\
\hline & $B$ & Beta & $t$ & $B$ & Beta & $t$ \\
\hline Intercept & $-0.3635^{* * *}$ & - & -12.8268 & $-0.4768^{* * *}$ & -0.0148 & 11.0518 \\
\hline Number of Employees & $-0.0698^{* * *}$ & -0.1978 & -10.0830 & $-0.1023^{* * *}$ & -0.3979 & -9.3580 \\
\hline Age of the firm & $-0.0398^{* * *}$ & -0.2874 & -10.7092 & $-0.0164^{* *}$ & -0.0843 & -2.4209 \\
\hline $\begin{array}{l}\text { Service } \\
\text { Diversification }\end{array}$ & $-0.0580^{* * *}$ & -0.0674 & --3.6864 & $-0.0428^{*}$ & -0.0574 & -1.8455 \\
\hline Human Capital & $-0.0288^{* * *}$ & -0.0406 & --3.1479 & $-0.0361^{* *}$ & -0.0816 & -2.3541 \\
\hline Number of branches & -0.0124 & -0.0357 & --1.4177 & -0.0087 & -0.0230 & -0.5611 \\
\hline $\begin{array}{l}\text { Hausman test: } \\
\chi^{2}(p \text { value })\end{array}$ & $\begin{array}{l}6.3851 \\
(0.2751)\end{array}$ & & & $\begin{array}{l}6.0465 \\
(0.3017\end{array}$ & & \\
\hline $\bar{R}^{2}$ & 0.1517 & & & 0.1775 & & \\
\hline Sample size & 2,986 & & & 708 & & \\
\hline
\end{tabular}

As different accounting services would entail different risks, we further analyzed the structure of services of each group of the sample to understand the service difference between male-owned and female-owned CPA firms. The results are presented in Table 6.

As shown in Table 6, attestation affairs constituted the main services of male-owned CPA firms. Male-owned CPA firms generated more revenues from these affairs than female-owned ones. Among large-sized CPA firms, male-owned firms took a larger share of the revenue in the categories of financial statements attestation (1,111.63 thousand dollars, 58.64 percent), other attestation affair (206.06 thousand dollars, 55.57 percent), and income tax attestation affair (206.06 thousand dollars, 54.24 percent). In terms of overall revenue from financial affairs, male-owned firms garnered 58.14 percent of the share (1,1317.69 thousand dollars). Similar findings can also be found among small-sized CPA firms and the entire sample. 
Table 6. Analysis of Service Composition by Firm Size and Owner's Gender

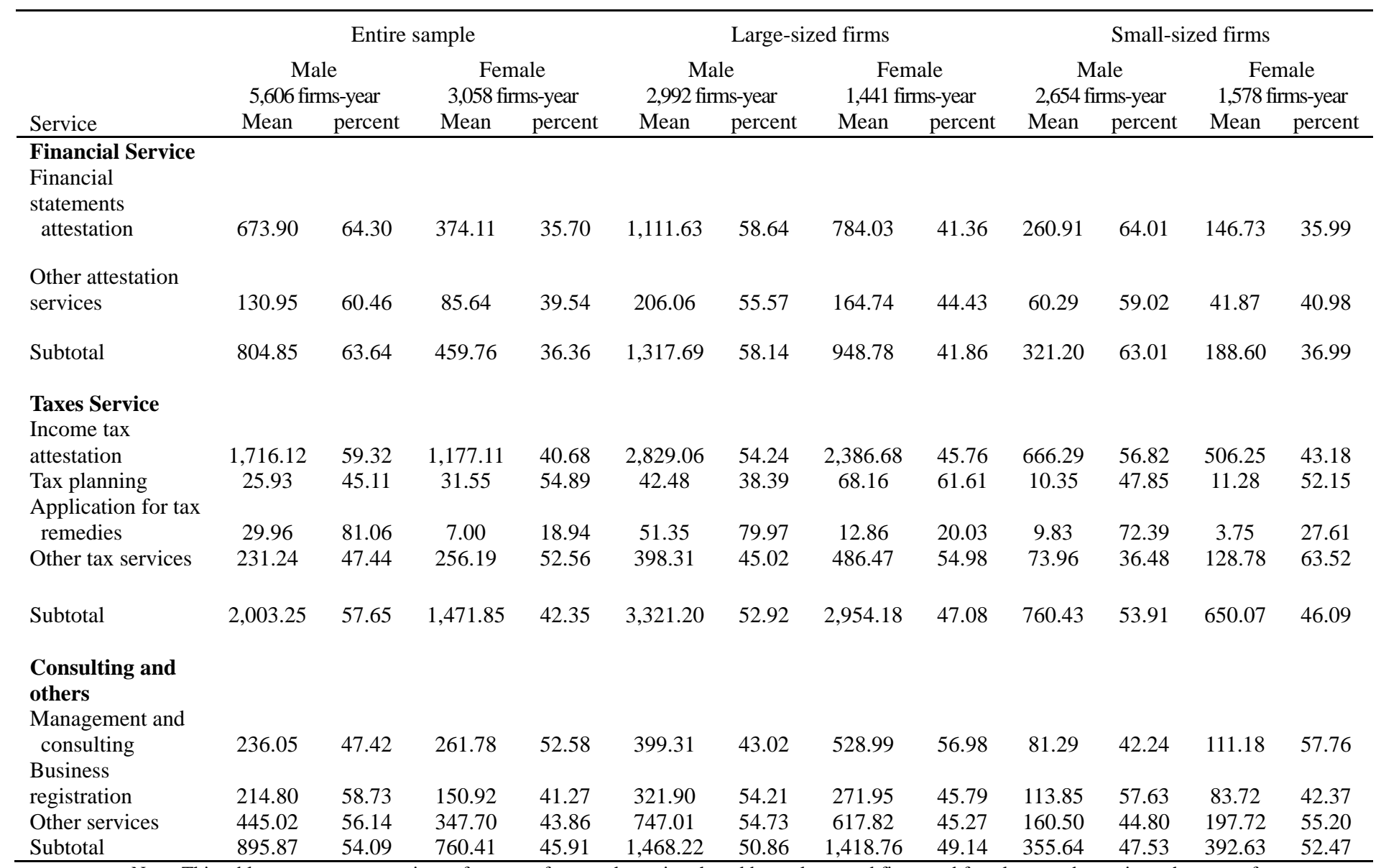

The above findings support the social feminist theory that men and women differ in rationality, mode of knowledge, and ways of sharing experiences and viewing the world. In the accounting industry, these differences would be reflected upon owners' preference of services. Essentially, attestation affairs involve higher risks than non-attestation affairs, mainly because the audit fee includes cost of audit effort and risk premium (Simunic, 1980; Lai, Kuo, \& Fu, 2007), which is expected to assume responsibility for attestation failure. Female owners seemed to have a systemic tendency to provide affairs of lower risks, which yielded relatively less profit. The aforementioned gender difference in risk preference is consistent with findings of previous research that women tended to use less risky and more robust strategies in making financial decisions (Sexton \& Bowman-Upton, 1990; Powell \& Ansic, 1997; Jianakoplos \& Bernasek, 1998; Kepler \& Shane, 2007). This difference will also be reflected upon women's motivation for entrepreneurship and business performance. As pointed out by Cliff (1998), most female-owned firms are of a smaller size, mainly because women owners are less active in business expansion and more concerned about business expansion risks.

\section{Discussion}

Traditional perspectives on the effects of gender difference on firm performance, attribute 
women underperformance in business mainly to unequal accessibility of resources (for example, financial resources), constraints of social mechanisms on women's competencies, and a social tendency that encourages women to receive historical and philosophical education (Alowaihan, 2004) rather than practical business education.

Liberal feminist theory would suggest that there should be no difference in the relative performance of female- and male-owned business if females are not discriminated against in terms of their access to important resources, i.e., education (Ahl, 2006). However, our results showed that female-owned CPA firms, especially large-sized ones, generated a significant lower level of profits than male-owned ones despite the fact that they all received the same professional accounting education. Hence, the barriers of social mechanisms (inequality) deemed by liberal feminist theory as the cause of women underperformance are seemingly unable to explain the phenomenon in this professional service industry.

The findings in Du Rietz and Henrekson (2000) indicated that female owners are comparable to male ones in profit performance but are less competent than male ones in overall sales performance. In contrast to male owners, female owners are less likely to set quick sales growth as their goal (Sexton, 1989; Rosa et al., 1996). In their business model, they prefer to view family and friends as a part of their business network. In this way, they can fulfill autonomy and maintain a balance between family and career through entrepreneurship (Goffee \& Scase, 1985; Carter \& Cannon, 1992; Fasci \& Valdez, 1998).

Although sole proprietorship accounting firms enables female owners to achieve economic independence and a balance between family and career (Fasci \& Valdez, 1998), this business model leads women to underperform in terms of revenue generated. In this study, we suggested, based on the social feminist theory, that female owners have a tendency towards providing low-risk services. One's choice of managerial strategies is affected by his or her risk preference (Schneider \& Lopes, 1986). Female owners are less risk-seeking because they tend to adopt operational strategies that can avoid adverse situations and satisfy their need for stability (Powell \& Ansic, 1997).

This study advances the understanding of the difference between men and women in their choice to pursue entrepreneurial business. Our results showed that female-owned CPA firms generated far less revenue than male-owned ones in the categories of attestation of financial reports and attestation of tax reports. In terms of revenue composition of female-owned CPA firms, revenue from non-attestation affairs took the largest share. It can be inferred that female owners preferred simpler and low-risk affairs, such as filing of tax applications and management consulting. Unlike attestation affairs which required them to meet clients outside the office, these relatively more static affairs allowed them to better maintain a family-business balance. Because these services generated relatively less profits in nature, female-owned CPA firms which depended heavily on them would certainly suffer a lower profit performance.

Previous research suggested that female owners are usually unfairly treated by banks and are difficult to access financing for entrepreneurship than male-owned ones (Riding \& Swift, 1990; Fay \& Williams, 1993; Coleman, 2000; Carter, et al., 2007). However, we argue that 
profit maximization is not the primary factor considered by creditors in providing loans to owners. High returns mean high risks, however, what concerns the creditors is low credit risk, that is, higher assurance of principal and interest collection. Although our empirical results indicated that female-owned CPA firms have lower profit performance, there is a smaller variation in their profit performance across different periods as the coefficient of variation for larger-sized female-owned firms $(\mathrm{CV}=0.61)$ is less than the one $(\mathrm{CV}=0.65)$ for male-owned firms. Their lower profit performance appears to stem from their lower risk preference. Fund providers may have higher intention to offer loans to less risk-seeking business owners because such lower risk preference can ensure stable collection of principal and interest. Therefore, we infer that female owners should be secure and conservative for their loan repayments and bank loan officer should have higher intention to offer fund to female owners.

In addition, we used a nationwide panel data obtained from a single nation to examine the relationship between owner's gender and profit performance among CPA firms. The robust results we obtained can be an important reference source for stakeholders, especially fund providers, of the professional service firms. Our results suggested that owner's gender is an indispensable factor of potential risks in financing. For financers, female owners of the professional service firms are less likely to default due to their use of more secure and conservative management strategies.

\section{Conclusions and Suggestions}

The impact of owner's gender on firm performance has been a topic issue in previous research. However, the empirical comparison of financial performance in male- versus female-owned firms has produced mixed results. In this study, we employ social feminism and choose the accounting industry consisting of a relatively sufficient female owner sample to examine the correlation between owner's gender and profit performance among CPA firms. Our main findings are summarized as follows:

First, among large-sized CPA firms, male owners had a higher profit performance than female ones. Second, a plausible reason is that most female CPA owners concentrated on providing non-attestation services. Third, female owners had a systemic tendency to provide services of lower risk. This tendency conforms to the argument of social feminist theory. In contrast to male owners, females are less risk-seeking in managing their business and setting up managerial strategies. This business style is less likely to guarantee high returns, thus affecting the profit performance of female owners.

With national and long-term panel data ensuring the robustness of its evidence results, this study focuses on female small business owners with a predilection for low risk. In particular, the study points out business management features of these owners which lead capital fund providers, when making their fund lending decisions, to consider that these female business owners' low-risk profit performance have lesser effect on bad debts of capital loan, and that loan interest can be steadily recovered. Therefore, the lower profit performance of female business owners will not hinder their ability to obtain external funding. 
In the accounting industry, many CPA firms are established by multiple partners. The effect of gender composition among all the owners of a firm on the firm's profit performance may be an intriguing issue for future research. Besides, the effect of the fit of owner's gender to employees on a firm's profit performance can also be a worthy issue to explore for future research.

\section{References}

Ahl, Helene (2006). Why research on women entrepreneurs needs new directions. Entrepreneurship Theory and Practice, 30(5), 595-621. http://dx.doi.org/10.1111/j.1540-6520.2006.00138.x

Alowaihan, A. (2004). Gender and business performance of kuwaiti small firms: A comparative approach. International Journal of Commerce and Management, 14(3/4), 69-81. http://dx.doi.org/10.1108/10569210480000185

Bröcheler, V., Maijoor S., \& Witteloostuijn, A. (2004). Auditor human capital and audit firm survival: The Dutch Audit Industry in 1930-1992. Accounting, Organizations and Society, 29 (7), 627-646. http://dx.doi.org/10.1016/j.aos.2003.10.008

Brush, C. G. (1992). Research on women business owners: past trends, a new perspective and future directions. Entrepreneurship Theory and Practice, 16(4), 5-30.

Carter, N. M. \& Williams, M. L. (2003). Comparing social feminism and liberal feminism: The case of new firm growth, in Butler, J. E. (Ed.), New perspectives on women entrepreneurs, Information Age Publishing, Greenwich, CT, pp. 25-50.

Carter, S. \& Cannon. T. (1992). Women as Entrepreneurs: A study of female business owners, their motivations, experiences, and strategies for success. Academic Press, London, England.

Carter, S., Shaw, E., Lam, W., \& Wilson, F. (2007). Gender, entrepreneurship, and bank lending: The criteria and processes used by bank loan officers in assessing applications. Entrepreneurship Theory and Practice, 31(3), 427-444. http://dx.doi.org/10.1111/j.1540-6520.2007.00181.x

Chaganti, R, \& Parasuraman, S. (1996). A study of the impacts of gender on performance and management patterns in small business. Entrepreneurship Theory and Practice, 21(2), 73-75.

Chen, Y., Chang, B., \& Lee, C. (2008). The association between continuing professional education and financial performance of public accounting firms. The International Journal of Human Resources $\quad$ Management, $\quad 19(9), \quad$ 1720-1737. http://dx.doi.org/10.1080/09585190802295363

Cliff, J. E. (1998). Does one size fit all? exploring the relationship between attitudes towards growth, gender, and business size. Journal of Business Venturing, 13(6), 523-542. http://dx.doi.org/10.1016/S0883-9026(97)00071-2

Coleman, S. (2000). Access to capital and terms of credit: A comparison of men- and women-owned small businesses. Journal of Small Business Management, 38(3), 37-52. 
Collins-Dodd, C, Gordon, I. M., \& Smart, C. (2004). Further evidence on the role of gender in financial performance. Journal of Small Business Management, 42(4), 395-417. http://dx.doi.org/10.1111/j.1540-627X.2004.00119.x

Coven, J. G. \& Slevin, D. P. (1991). A conceptual model of entrepreneurship as firm behavior. Entrepreneurship Theory and Practice, 16(1), 7-22.

DeTienne, D. R. \& Chandler, G. N. (2007). The role of gender in opportunity identification. Entrepreneurship Theory and Practice, 31(3), 65-386. http://dx.doi.org/10.1111/j.1540-6520.2007.00178.x

Du Rietz, A. \& Henrekson, M. (2000). Testing the female under-performance hypothesis. Small Business Economics, 14(1), 1-10. http://dx.doi.org/10.1023/A:1008106215480

Fasci, M. A., \& Valdez, J. (1998). A performance contrast of male- and female-owned small accounting practices. Journal of Small Business Management, 36(3), 1-7.

Fay, M. \& Williams, L. (1993). Gender bias and the availability of business loans. Journal of Business Venturing, 8(4), 363-376. http://dx.doi.org/10.1016/0883-9026(93)90005-P

Fischer, E. M., Reuber, A. R. \& Lorraine S. D. (1993). A theoretical overview and extension of research on sex, gender, and entrepreneurship. Journal of Business Venturing, 8(2), 151-168. http://dx.doi.org/10.1016/0883-9026(93)90017-Y

Goffee, R. \& Scase, R. (1983). Business ownership and women's subordination: a preliminary study of female proprietors. Sociological Review, 31(4), 625-648. http://dx.doi.org/10.1111/j.1467-954X.1983.tb00724.x

Gold, A., Hunton, J. E., \& Gomaa, M. (2009). The impact of client and auditor gender on auditors' judgments. Accounting Horizons, 23(1), 1-18. http://dx.doi.org/10.2308/acch.2009.23.1.1

Greenwood, R., Hinings, C. R., \& Brown, J. (1990). P2-Form strategic management: corporate practices in professional service firms. Academy of Management Journal, 33(4), 725-755. http://dx.doi.org/10.2307/256288

Greenwood, R., Li, S. X., Prakash, R. \& Deephouse, D. L. (2005). Reputation, diversification, and organizational explanations of performance in professional service firms. Organization Science, 16(6), 661-722. http://dx.doi.org/10.1287/orsc.1050.0159

Gupta, V. K., Turban, D. B., Wasti, S. A., \& Sikdar, A. (2009). The role of gender stereotypes in perceptions of entrepreneurs and intentions to become an entrepreneur. Entrepreneurship Theory and Practice, 33(2), 397-417. http://dx.doi.org/10.1111/j.1540-6520.2009.00296.x

Hisrich, R. \& Brush, C. (1984). The woman entrepreneur: management skills and business problems. Journal of Small Business Management, 22(1), 30-37.

Hitt, M. A., Bierman, L., Shimizu, K. \& Kochhar, R. (2001). Direct and moderating effects of human capital on strategy and performance in professional services firms: a resource-based 
perspective. Academy of Management Journal, 44(1), 13-28. http://dx.doi.org/10.2307/3069334

Hughes, K. D., Jennings, J. E., Brush, C., Carter, S., \& Welter, F. (2012). Extending women's entrepreneurship research in new directions. Entrepreneurship theory and Practice, 36 (3), 429-442. http://dx.doi.org/10.1111/j.1540-6520.2012.00504.x

Inmyxai, S. \& Takahashi, Y. (2010). Performance contrast and its determinants between male and female headed firms in Lao MSMEs. International Journal of Business and Management, 5(4), 37-52.

Jianakoplos, N. \& Bernasek, A. (1998). Are women more risk averse?. Economic Inquiry, 36(4), 620-630. http://dx.doi.org/10.1111/j.1465-7295.1998.tb01740.x

Johnsen, G. J. \& McMahon, R. G. (2005). Owner-manager gender, financial performance and business growth amongst SMEs from Australia's business longitudinal survey. International Small Business Journal, 23(2), 115-142. http://dx.doi.org/10.1177/0266242605050509

Jones, K, \& Tullous, R. (2002). Behaviours of pre-venture entrepreneurs and perceptions of their financial needs. Journal of Small Business Management, 40(3), 233-249. http://dx.doi.org/10.1111/1540-627X.00053

Kalleberg, A. L. \& Leicht, K. T. (1991). Gender and organizational performance: determinants of small business survival and success. Academy of Management Journal, 34(1), 136-161. http://dx.doi.org/10.2307/256305

Kennedy, P. (1992). A Guide to Econometrics, 3rd ed, MIT Press, Cambridge, M. A.

Kepler, E., \& Shane, S. (2007). Are male and female entrepreneurs really that different?. Working Paper, Small Business Association, Office of Advocacy, under Contract Number SBAHQ-06-M-0480.

Kuhn, P. (1987). Sex discrimination in labor markets: the role of statistical evidence. American Economic Review, 77(4), 567-583.

Lai, Y., Kuo, C., \& Fu, C. (2007). Risk Premium Perspective-Audit Value of the Private Colleges and Universities in Taiwan. Journal of Accounting and Corporate Governance, 4(1), 1-33.

Lei, D. \& Slocum, J. W. (2005). Strategic and organizational requirements for competitive advantage. Academy of Management Executive, 19(1), 31-45.

Lerner, M. \& Almor, T. (2002). Relationships among strategic capabilities and the performance of women-owned small ventures. Journal of Small Business Management, 40(2), 109-125. http://dx.doi.org/10.1111/1540-627X.00044

Lerner, M., Brush, C., \& Hisrich, R. (1997). Israeli women entrepreneurs: an examination of factors affecting performance. Journal of Business Venturing, 12(4), 315-339. http://dx.doi.org/10.1016/S0883-9026(96)00061-4 
Loscocco, K. \& Leicht, K. T. (1993). Gender, work-family linkage, and economic success among small business owners. Journal of Marriage and the Family, 55(4), 875-887. http://dx.doi.org/10.2307/352769

Lowe, M., \& Bentson, M. (1984). The uneasy alliance of feminism and academia. Women's Studies International Forum, 7(3), 177-83. http://dx.doi.org/10.1016/0277-5395(84)90008-6

Ministry of Education, (2012a). Summary of education at all levels SY2000-2012. . Available at: http://english.moe.gov.tw/public/Attachment/26129455729.xls (accessed 26 June 2012).

Ministry of Education, (2012b). The statistics of study subjects categories at the university level. available at: http://www.edu.tw/files/site_content/B0013/bcode_u.xls (in Chinese), (accessed on 26 June 2012).

Morris, T. \& Empson, L. (1998). Organisation and expertise: an exploration of knowledge bases and the management of accounting and consulting firms. Accounting, Organisations and Society, 23(5/6), 609-624. http://dx.doi.org/10.1016/S0361-3682(98)00032-4

Nordenflycht, A. (2010). What is a professional service firm? toward a theory and taxonomy of knowledge-intensive firms. Academy of Management Review, 35(1), 155-174. http://dx.doi.org/10.5465/AMR.2010.45577926

Palupu, K. G., Healy, P. M., Bernard, V. L. \& Peek, E. (2009), Business Analysis and Valuation, IFRS Edition, Thomson/South-Western, Ohio, US.

Porter, E. (1994). Feminist analysis,. $\quad$ in Parkin, A., Summers, J., and Woodward, D. (Ed.), Government, Politics, Power and Policy in Australia, Pearson Education, Australia.

Powell, M. \& Ansic, D. (1997). Gender differences in risk behaviour in financial decision-making: an experimental analysis. Journal of Economic Psychology, 18(6), 605-628. http://dx.doi.org/10.1016/S0167-4870(97)00026-3

Robb, A. M. \& Watson, J. (2011). Gender difference in firm performance: Evidence from new ventures in the US. Journal of Business Venturing, 27(5), 544-558. http://dx.doi.org/10.1016/j.jbusvent.2011.10.002

Rosa, P., Carter, S., \& Hamilton, D. (1996). Gender as a determinant of small business performance: insights from a British study. Small Business Economics, 8(6), 463-478. http://dx.doi.org/10.1007/BF00390031

Schneider, S. L. \& Lopes, L. (1986). Reflection in preference under risk: who and when may suggest why. Journal of Experimental Psychology: Human Perception and Performance, 12(4), 535-548. http://dx.doi.org/10.1037/0096-1523.12.4.535

Sexton, D.L. \& Bowman-Upton, N. (1990). Female and male entrepreneurs: psychological characteristics and their role in gender-related discrimination. Journal of Business Venturing, 5 (1), 29-36. http://dx.doi.org/10.1016/0883-9026(90)90024-N 


\section{Macrothink}

Asian Journal of Finance \& Accounting

ISSN 1946-052X 2013, Vol. 5, No. 1

Sexton, Donald (1989). Research on women business owners', in Hagen, O., Rivchun, C., and Donald L. (Ed.), Sexton Women Owned Businesses, Praeger, New York, 183-193.

Sherer, P. D. (1995). Leveraging human assets in law firms: human capital structures and organizational capabilities. Industrial and Labor Relations Review, 48(4), 671-691. http://dx.doi.org/10.2307/2524350

Shinnar, R. S., Giacomin, O., \& Janssen, F. (2012). Entrepreneurial perceptions and intentions: the role of gender and culture. Entrepreneurship theory and Practice, 36(3), 465-493. http://dx.doi.org/10.1111/j.1540-6520.2012.00509.x

Simunic, D. A. (1980). The pricing of audit services: theory and evidence. Journal of Accounting Research, 18(1), 161-190. http://dx.doi.org/10.2307/2490397

Watson, J. (2002). Comparing the performance of male- and female-controlled businesses: relating outputs to inputs. Entrepreneurship Theory and Practice, 26(3), 91-100. 